\title{
Effects of the age-education structure of female workers on male earnings in Brazil
}

\author{
Ernesto F. L. Amaral \\ Universidade Federal de Minas Gerais (UFMG), Brazil \\ eflamaral@gmail.com \\ Mariana Eugenio Almeida \\ Fundação João Pinheiro (FJP), Brazil \\ mariana.almeida88@gmail.com \\ Eduardo Luiz Gonçalves Rios-Neto \\ Universidade Federal de Minas Gerais (UFMG), Brazil \\ eduardo@cedeplar.ufmg.br \\ Joseph E. Potter \\ University of Texas at Austin \\ joe@prc.utexas.edu
}

\begin{abstract}
The main concern of this study is the impact that an increase in female participation within the labor force has on the earnings of males in Brazil. Previous research considered these transitions for male workers, but did not include female workers when estimating various effects on earnings. The 1970, 1980, 1991, and 2000 Brazilian Demographic Censuses were used for this analysis. Results suggest a significant negative impact on male earnings in 1970 as a result of the share of female workers. This effect has been decreasing over time, as the coefficients from more recent years are positive. Changes in age and educational composition make a substantial difference on the estimation of male earnings in Brazil. The method developed in this study is not infallible, but it improves previous estimates by including the relationship among compositional changes, female labor force participation, and earnings, thus going beyond the direct impact of age and education.
\end{abstract}

\section{Keywords}

Age and educational transitions, Economic development, Income inequality, Gender inequality, Female labor force participation, Brazil

\section{Acknowledgments}

This research received support from the Institute for Applied Economic Research ("Instituto de Pesquisa Econômica Aplicada" - IPEA) and the Coordination for the Improvement of Higher Education Personnel ("Coordenação de Aperfeiçoamento de Pessoal de Nível Superior" - CAPES) of the Brazilian Ministry of Education ("Ministério da Educação" - MEC), through the IPEA/CAPES Program for Development ("Programa Cátedras IPEA/CAPES para o Desenvolvimento" - 001/2010). This research project received financial support from the Minas Gerais Research Support Foundation ("Fundação de Amparo à Pesquisa do Estado de Minas Gerais" - FAPEMIG) to be presented at the International Seminar on Patterns of Economic Development, Social Change, and Fertility Decline in Comparative Perspective: Analysis and Policy Implications, held in Shanghai, China, May 25-27, 2012. We acknowledge Professor Juarez Rocha Guimarães for directing us to the readings of Celso Furtado about the history of economic inequality in Brazil. We would like to thank Adriane Reams for editing this article.

\section{Final publication}

Amaral EFL, Almeida ME, Rios-Neto ELG, Potter JE. 2013. "Effects of the age-education structure of female workers on male earnings in Brazil." Poverty \& Public Policy, 5(4): 336-353.

(http://dx.doi.org/10.1002/pop4.54) 


\section{Introduction}

The impact of demographic and educational transitions on the earnings of Brazilian is the main concern of this study. Previous research (Amaral et al., 2007) has considered male workers. The present research includes female workers in the estimations. However, when including female workers in models that estimate the impact on male earnings, one must consider the two-way relationship between fertility and female labor force participation. Women who are not in the labor force do not compete with women who are in the labor force. Fertility explains labor force participation. At the same time, the decision to participate in the labor market influences fertility levels. Thus the aim of the present study is to analyze how the age-education structure of female workers affected male earnings in Brazil between 1970 and 2000.

The theoretical support for this study is summarized in the second section. The persistence of economic inequality in Brazil is discussed based on Furtado's studies (1975, 1979, 1984, 2002, 2003, and 2009). There is a connection between income inequality and the issue of women and gender inequality. Because of the disproportionate concentration of wealth, the country has failed to achieve a satisfactory level of economic development. There may be economic growth, but there is little economic development in Brazil. Furtado notes that development would be boosted if the pronounced regional inequality did not exist.

An increase in female labor force participation could contribute to reducing economic inequality (Esping-Andersen, 2009; Esping-Andersen et al., 2002), which would ignite economic development. Brazil has experienced an increase of female participation in the workforce, but gender inequality contributes to the country's state of underdevelopment. The third section of this paper deals with this increase of female workers in the labor market. The fourth section presents the data and methods used in our estimates, followed by a section that analyses the results generated by our data and models. We conclude with a discussion of some considerations and possible consequences regarding the topic. 


\section{The history of economic inequality in Brazil}

In order to understand the economic inequality that persists in Brazil, the work of Celso Monteiro Furtado must be taken into account, as he was the first author to address the structural issue of development by emphasizing regional and internal market inequalities in the country (Mendes and Teixeira, 2004).

Furtado, a notable Brazilian economist and intellectual, developed a "regional-historical-structuralist" methodological framework (Mendes and Teixeira, 2004). The concept of a structuralist analysis was first conceived of by Raul Prebisch in the context of the United Nations Economic Commission for Latin America and the Caribbean (ECLAC). Prebisch's theory was based on the characterization of peripheral and underdeveloped economies in contrast with centralized and developed economies. Furtado altered this structuralist approach with the addition of three aspects (1) the inclusion of a historical perspective; (2) the analysis of the relationship between growth and income distribution; and (3) the emphasis of the cultural system as a specific characteristic of underdevelopment in peripheral economies (Mendes and Teixeira, 2004). A key point in this framework is that economic differences across regions are a limiting factor for the Brazilian development project. Furthermore, the market is an entity that is unable to regulate itself, requiring the intervention of the state planning board. Underdevelopment should not be classified as a phase that all societies must tackle in order to become a developed nation, but rather as a process that is qualitatively different from the experience of more developed centralized countries. Underdevelopment is a product of capitalist expansion, which replicates the asymmetry between a country's industrial center and the exploited periphery. This process often generates regional inequalities within the underdeveloped countries.

There are various explanations for the way in which the Brazilian economic structure developed (Furtado, 1979). Different economic and historical contexts generate peripheral countries. Furtado compared Brazil to the United States in order to explain Brazil's legacy of economic underdevelopment. It is significant to note that in the 17 th century, the American economy was based on small farms that had lower productivity than other agricultural exporting colonies like Brazil. However, there was less income inequality in the United States than in Brazil. Consequently, there are major differences in the behavior of 
the dominant social groups in these two nations. In Brazil, ties were formed with financial groups in Portugal. In the United States and Canada, the territories enjoyed widespread autonomy with their colonial powers. Furtado also analyses the difficulties involved in establishing internal markets, developing the economy, and diversifying production in Brazil. At the time when Brazil gained its independence, the country did not have a developed internal market, business structure, or support for industrialization from ruling classes. The American colonies exemplified all of these characteristics at the end of its colonial era. Contrary to what happened in the United States, there was a decline in domestic consumption in Brazil, which hampered the progress of industrialization.

During the period of slavery in Brazil, Furtado (1979) suggests that the sugar cane industry created favorable conditions for economic development. However, income was concentrated in the hands of plantation owners. As a result of this structure, the internal market did not expand, which precluded economic development. The economic framework of sugar cane production in the Brazilian Northeast lasted for more than three centuries. At times the system recovered from external market depressions, without suffering any significant structural change. However, the Northeastern economy suffered stagnation between the last quarter of the 17 th century and the early 19 th century. During these periods the main components of the Brazilian economy were the sugar cane and livestock industries, which also continue to shape key elements of the more recent economy.

Furtado continues by analyzing the mining industry, which also primarily utilized slave labor. Mining developed in the Central-South areas of Brazil, and coexisted with the ranching industry that was already in place in the area. The partnership between mining and ranching promoted an integrated economy in this region (Bielschowsky, 2009).

As he expands his analysis, Furtado also explores the coffee industry in Brazil. At the end of the 18th century, the coffee industry suffered as a result of the abolition of slavery in several ways: (1) expansion of a subsistence economy; (2) reduction of productivity; and (3) increased labor shortage. The solution to these problems was the utilization of European laborers who had immigrated to Brazil, which contributed to the permanence of a subsistence economy. During this period, Brazil was unable to 
integrate its economy as a component of the world market. Developed countries were experiencing economic transformations at this time, which were not assimilated by Brazilian society. This process caused friction between the economic systems of developed countries and Brazil. Furtado's "structuralist" perspective emphasizes these challenges that effected development caused by the coexistence of modern and subsistence sectors, as well as by a non-diversified production system.

Regarding the period between the mid-19th and mid-20th centuries, Furtado (1979) analyzes the expansion of the coffee sector and the transition to an industrialized economy. Challenges arose in Brazil as industrialization occurred too quickly in an economy that had been characterized by a traditional structure. This process transformed Brazil from a primarily exporting economy to an industrial economy. This transition created economic development problems for the country, since Brazil had not improved its internal market activities, which are necessary during the industrialization process. Along with the lack of a functional internal market, widespread income inequality in the country favored economic stagnation. Thus, a redistribution of income was essential to the country's economic growth. However, the previous concentration of income was maintained because institutional factors prevented or at least hindered this needed development. There has long been a tendency to exclude much of the population from the benefits of the process of economic growth and technological progress throughout Brazil's history. The regime of land ownership was also detrimental to development, because it fostered the emergence of social structures that are disconnected from the production process. Furtado's argument centers around the idea that agrarian restructuring and a redistribution of income is necessary to reform the Brazilian style of production development.

Furtado (2003) also discusses the cultural aspects of underdeveloped nations. Some countries have the potential for economic growth through the primary sector (agriculture, fishing, extraction, and direct use of natural resources). Through this process the nation's income would increase, but the bulk of the new wealth would only benefit an elite group. This elite minority would adopt consumption and lifestyle patterns that are typical of wealthy countries, but are incompatible with the income level of their own country. This country would grow economically, but would not develop economically. This 
perspective fits the Brazilian model, in which the benefits of economic growth and technological changes are unevenly distributed across population sectors. The increase of per capita income, without even distribution amongst all social classes, reflects the reproduction of the consumption patterns of developed countries. This scenario results in large regional inequalities, as well as in a limited domestic market (Mendes and Teixeira, 2004).

The dramatic regional discrepancies in Brazil are the central elements that affect the industrialization process in the country (Furtado 2003). Income distribution is closely linked to regional disparities. Industrialization began simultaneously in almost all regions of the country. However, the industrialization process tended to be concentrated in the Southeast region. The decisive step cementing this concentration occurred during World War I, a time when the first phase of industrial acceleration occurred. At this time, the Brazilian federal government invested in machinery to promote the modernization of industry. However, no actions were taken to decentralize this economic development across the different regions of the country. This centralization process was intensified during the postWorld War II period, resulting in an intensified disparity in per capita income levels among regions. This economic inequality led to regional tensions, which became a major political concern in Brazil. In this sense, economic integration is necessary for growth, but will only emerge when archaic production techniques are improved and the country's resources are properly harnessed. Issues such as national economic integration, joint use of resources, and fear of regional conflicts are central factors when conducting a structural analysis of Brazil. Furtado used a "historical-regional-structural" perspective, as he believed that the country's numerous regions experienced unique developments at varying times, resulting in distinct localized economic structures (Mendes and Teixeira, 2004). The issue of regional planning was significant to Furtado's framework, as is reflected by his career as a public manager, with the greatest example being his creation of the Agency for the Development of the Northeast (Superintendência do Desenvolvimento do Nordeste - SUDENE).

He argues that an articulated economic system, with consistent and autonomous decision centers, could only be achieved through the development of the Brazilian internal market (Furtado, 1975). 
However, in the context of the development of industrial capitalism, the established economies dictated technological progress (Furtado 1984). These countries experienced a rapid accumulation of wealth, which was the driving force that influenced transformations around the world. The other countries constituted the peripheries of the system. The strategic decisions of the countries with established economies shaped the economic and social structures of the periphery. Brazil's position as a peripheral power has compromised its technological progress and the development of a productive economic structure. This has hindered the improvement of the nation's financial system (Fiori, 2000). Brazil occupies a peculiar position on the periphery, because of its extensive unified territory. However, Brazil's elite has failed to build and develop a unifying national economic goal.

Furtado's analysis emphasizes that there is a relationship between economic development and overall social structure (Furtado 1975, 1979, 1984, 2002, 2003, 2009). The idea of substitution of importation and industrial development combines elements that are present in ECLAC theory: (1) the diversification of the production structure; (2) the size of the internal market; and (3) the ability to import (Mendes and Teixeira, 2004). This perspective was observed in Brazil during the 1940s when the state played a direct centralized role in the industrialization of the country. During President Juscelino Kubitschek's administration, Furtado proposed changes within the national economic system in an attempt to bring real industrial growth and economic development. His policies to expand the economy required protection, planning, and encouragement from the government in relation to the industrial sector. Among other things, this industrialization process would: (1) generate economic policies to encourage a culture of consumption; (2) overcome the archaic agrarian system; (3) create changes in the distribution of wealth, as a means of encouraging and expanding the domestic market; and (4) reduce regional inequalities (Mendes and Teixeira, 2004).

In terms of a political system, Furtado points to the democratic model as the best alternative to achieve development (Nabuco, 2000). Under Furtado's political ideas, economic development would generate better revenue for the country through a process of decreased income inequality. However, because of the perverse Brazilian agrarian structure, economic growth eventually heightened regional 
inequalities. Economic growth depends on the distribution of income, but it can occur even when there is a focused concentration of income. Due to an absence of effective public policies, this structure eventually resulted in a greater concentration of income that favored specific groups. This analysis is still currently relevant, since a major challenge for Brazil is in reversing its economic inequality. This challenge can only be achieved with public policies that consider the regional heterogeneity of the country and the importance of its internal market (Mendes and Teixeira, 2004). In this sense, economic growth is not enough to overcome the underdevelopment of a nation. Broad structural reform is needed to mitigate social and economic inequalities. Brazil must optimize its internal market, in order to promote national economic development that is less vulnerable to external factors.

The regional inequality that Furtado highlights is one of the many components of social inequality that characterizes Brazil. Gender inequality has also been identified as a serious social problem in the country (Alves and Corrêa, 2009). The income disparity between men and women is notable, and this uneven distribution is the subject of research in several countries. In line with Furtado's theories, gender inequality is an obstacle to economic development, because it augments overall inequality. In Brazil, the income gap between men and women has decreased since the 1950s and the participation of women as a component in the economically active population has steadily increased. This process of women entering the labor market is one of the great changes in the second half of the 20th century in Brazil. On the demand side, the process of urbanization and the growth of the tertiary sector of the economy (production and provision of services, also known as the service sector or the service industry) have opened up the productive insertion of women into the labor market. On the supply side, the decline in fertility, changes in marital and family dynamics, as well as increasing average educational levels have made the female workforce essential to the development of the country (Alves and Corrêa, 2009). This act of making the female workforce a valuable commodity is significant to the country's economic development, as it may result in reducing the income gap between men and women. Overall, Brazil is moving in a positive direction toward greater gender equality with an increasing integration of women into the labor market. Although progress is being made, inequalities still remain, including gender issues, 
which contribute to the country's permanent state of underdevelopment. The next section analyzes the increase of female participation in the labor market and its importance to Brazil's economic development.

\section{The increase in female labor force participation}

The increasing integration of women into the job market is a phenomenon that has been occurring in several countries worldwide, with a spike in participation occurring during the period after World War II (Souza, 2009). This trend has shaped the international job market, but it has also affected the traditional family structure. The relationship between economic structure and an increase in female labor force participation is a key factor for understanding the gender changes that have occurred in several countries. In general, when women enter the workforce and receive paid employment, an overall restructuring can occur, which often includes an increase in employment services, more flexible work hours, and new patterns of industrial relations (Daly and Rake, 2003).

In addition to women entering the job market at an escalated rate, the post-World War II period was marked by a series of transformations that affected family structure and gender relationships. In several countries, there have been trends towards reducing fertility rates, an escalated divorce, and increased participation of married women with young children in the job market (Souza, 2009). In general, the male breadwinner model (male head-of-household model) has increasingly been abandoned. Women have been giving birth to fewer children, and the age at which women have their first child has increased. According to Esping-Andersen (2009), changes such as these are related to the new position of women in society.

When considering the labor market, the transformation occurred earlier and more quickly in the Scandinavian countries, with many changes occurring in the 1960s (Esping-Andersen, 2009). However, countries like England, for example, have been undergoing a slow and gradual process, which suggests that the progression of the new role of women is incomplete. Moreover, prior to the 1990s, much of the increase in female participation in the labor market was only related to part-time work. In more recent decades, this scenario has changed, and women are increasingly involved in full-time work. In the Nordic 
countries, there are virtually no housewives, and part-time work is considered to be a temporary alternative that bridges the transition between maternity leave and a return to full-time work. Increasingly more women are committed to paid employment. This transformation has several implications, including financial independence and the fact that women are now more independent in the workplace. This phenomenon is particularly true for more educated women.

It is important to emphasize the relationship between motherhood and a woman's decision to enter or return to the job market (Esping-Andersen, 2009). Women, especially those who are educated, are generally devoting less time to the period of motherhood than in the past. Thus, changes that occurred after women were included in the job market affect decisions regarding family and motherhood. In this sense, the new roles women have adopted are directly related to the overall decline in marriage rates, the increase in family instability, the emergence of atypical family structures, and the decline of fertility rates. However, the decreased marriage rates among women who have entered the job market are more intensified among less educated women. In other words, the movement away from conventional marriage patterns has proven to be stronger among women whose job status has less variation. Furthermore, alternative relationships have emerged which include cohabitation and having children out of wedlock.

In the context of the changes that have been observed during the past several decades, there is variation among European countries with respect to the average number of children per woman. In Eastern Europe, there was a significant decrease in fertility rates in the 1990s (Work Care Synergies, 2011), which may have been related to political changes that led to the cancelation of certain public services. Beginning in the 2000s, these estimates increased, which may have been related to recent economic and social transformations that have occurred in the context of being integrated as a part of the European Union.

In Central Europe, France stands out as having had a significant increase in fertility rates during the last decade, which was related to the implementation of various policies in support of natality (Work Care Synergies, 2011). In turn, Nordic countries have the highest fertility rates in Europe. In these countries, there are a wide range of polices that support families and gender equality. These policies 
contribute to the maintenance of high fertility rates. Finally, in Southern Europe, fertility rates are the lowest in Europe. These low rates are most likely related to the immaturity of policies that support families and natality in these countries. In Greece, Spain, and Italy, fertility rates have increased over the last decade, whereas in Portugal, the fertility rate has decreased.

The increase in female participation in the job market is a phenomenon that contributes to the process of demographic transition (Soares and Falcão, 2008). The transition is initially characterized by lower mortality and fertility rates. The changing role of women in society can be partially attributed to the impact of reduced mortality on family decisions. In this context, the increase in life expectancy and the decrease in family size have a positive effect on female participation in the workforce, and these factors contribute to reducing the income gap between men and women.

In addition to changes in fertility and mortality rates, the average marriage and maternity ages of women have increased in recent decades (Esping-Andersen, 2009). This process reveals a new scenario that is marked by a longer period of education, higher rates of unemployment among the young, and limited access to the property market. There is a positive correlation between fertility rates and rates of female labor force participation in some European countries, which is contrary to prior decades when this correlation was negative.

The same pattern occurs in relation to schooling. The previous association between female education and fertility was negative, but this correlation becomes positive in the Nordic countries (Esping-Andersen, 2009; Esping-Andersen et al., 2002). More educated women became pioneers and revolutionized women's roles. Varying levels of education, that are unique to each country, influence the relationship between female education and fertility rates.

Although the changes in recent decades represent a step toward greater gender equality, there are some negative effects (Esping-Andersen, 2009). The revolution of the role of women is incomplete for several reasons. Overall, women are having fewer than their desired number of children and are investing less in childcare, in terms of education, healthcare, and nutrition. Fertility decline affects the, age structure of populations by diminishing the proportion of children, and increasing the proportion of the older 
population. Thus, this process generates a large elderly population, which requires escalated public policies related to retirement, social security, and pensions. The increase of single-parent families can also increase inequality, because more vulnerable families are created. A desire and interest in motherhood remains strong among women, which results in one of the most controversial dilemmas of modern society: the reconciliation between career and motherhood. Indeed, the structures of social welfare play a critical role in balancing work and making motherhood more affordable. Many welfare states were not able to support these benefits, which resulted in an increase of inequality.

These changes may be related to the emergence of new risks and social inequalities (EspingAndersen, 2009). There has been an increase in income inequality in several European countries, such as Denmark, Norway, Sweden, France, Germany, Italy, Spain, and the United Kingdom, as well as in the United States. This phenomenon is most likely a result of changes in the economy, family structure, and women's position in society. According to Esping-Andersen (2009), the paradox that arises is that the quest for gender equality can generate social inequality. This problem occurs when these changes are concentrated among women with a higher economic status. Women with less education generally have less access to the job market, albeit to a lesser extent in the Nordic countries. If we assume that labor income has a positive correlation to increased education, then women entering the labor market can contribute to income inequality. For example, a couple with an advanced education who are inserted into the labor market would have an advantage over the rest of the population, especially if unemployment is higher among less skilled individuals. Thus, if the increased involvement of women in the job market is concentrated among more educated women or among women who are married to men with higher incomes, inequality would increase. On the contrary, if the insertion of women into the labor market was more pronounced among less skilled women, there could be a decrease in income inequality.

Finally, the income gap between men and women has overall been decreasing over the past decades. This is a result of women entering the job market, having lower fertility rates, and taking fewer maternity leaves (Blau and Kahn, 2003; Esping-Andersen, 2009). However, women in general, and particularly less educated women, are more vulnerable to economic crises. 
In relation to Brazil, the increase in female participation in the labor market has been occurring since the 1970s (Costa, 1990; Rios-Neto and Wajnman, 1994; Souza, 2009; Wajnman, Queiroz, and Liberato, 1998). According to the Brazilian Institute of Geography and Statistics (Instituto Brasileiro de Geografia e Estatística - IBGE), the proportion of economically active women ranged from 47.17 percent in 1997 to 50.27 percent in 2002, and 52.35 percent in 2007 (Souza, 2009). Women with varying characteristics have had higher workforce participation rates since the 1980s. In other words, the increase in female participation in the Brazilian job market occurred regardless of age, race, marital status, socioeconomic status, or region of residence (Rios-Neto and Batista, 1998; Souza, 2009). However, despite their increasing participation in the labor market, women continue to earn less than men, even when their education levels are equal (Alves and Corrêa, 2009). Despite the increase in the participation of female labor being extremely important for the growth of Brazil, a tradition of economic instability and gender inequalities still remain. While differences in income have not been eliminated, they have been significantly reduced, especially in the formal labor market.

Returning to Furtado's framework, women entering the labor market may contribute to economic growth, but the enduring income inequality between men and women is a hindrance to the country's economic development. However, Brazil has taken steps towards a process in which women entering the job market will have the opportunity to play a key role in the county's future economic development Alves and Corrêa, 2009). The next section presents the data and methods used to estimate the impact of the increasing participation of the female labor force on male earnings in Brazil, taking into account regional disparities, emphasized by Furtado's research.

\section{Data and methods}

The 1970, 1980, 1991, and 2000 Brazilian Demographic Censuses were collected by the Brazilian Institute of Geography and Statistics (Instituto Brasileiro de Geografia e Estatística - IBGE) and were used for the present study. We aggregated the microdata in cells by micro-region, age-education, and year. Taking into account the sample design (frequency weights), we estimated the mean income and the 
proportion of men in each age-education group by year and micro-region. Because our estimates utilized 502 micro-regions, 12 age-education groups, and four Censuses, the maximum number of possible observations in the regressions was 24,096 . However, the requirement that there be at least 25 individuals in a cell resulted in the exclusion of some observations. Thus, we reduced the estimates to 19,727 microregion/year/age/education cell observations.

The regression model presented below is a fixed effect equation that explains variation in earnings for the male population. We introduced area and time fixed-effects in order to take into account regional disparities over the years, as is suggested by the historical analysis of income inequality in Brazilian (Furtado, 1975, 1979, 1984, 2002, 2003, 2009). Furthermore, we expected to see a positive impact when considering age within each education group. This positive impact was also anticipated with increased education within each age group. Because of these anticipated impacts, we included the effect of changing the age-education composition on earnings. A set of variables was added to the model to estimate the impact of own-cohort size on earnings. Our main hypothesis was that cohort size has a negative impact on earnings. Equation (1) illustrates these estimations:

$\log \left(Y_{i j r t}\right)=s_{i}+x_{j}+\gamma_{r}+\pi_{t}+X_{i j r t}+\left(s_{i} * x_{j}\right)+\left(s_{i} * \pi_{t}\right)+\left(x_{j} * \pi_{t}\right)+\left(\gamma_{r} * \pi_{t}\right)+\left(X_{i j r t} * \pi_{t}\right)+\left(s_{i} * x_{j} * \pi_{t}\right)+\varepsilon_{i j r t}$,

where $\log \left(Y_{i j r t}\right)$ is the logarithm of the mean real monthly earnings from the main occupation of the male working-age population with education $i(i=0-4,5-8,9+$ years of schooling) and experience $j(j=15-24$, 25-34, 35-49, 50-64 years of age). The earnings are observed by micro-region $r(r=1, \ldots, 502)$ at time $t$ ( $t=1970,1980,1991,2000)$. Finally, $s_{i}$ is a vector of fixed effects that indicates the group's educational attainment, $x_{j}$ is a vector of fixed effects that indicates the group's work experience, $\gamma_{r}$ is a vector of fixed effects that indicates the micro-region, and $\pi_{t}$ is a vector of fixed effects that indicates the time period. The linear fixed effects control for differences in earnings across schooling groups, experience groups, and micro-regions over time. We added the distribution of males by age-education group from each micro-region and year $\left(X_{i j t}\right)$. The interaction $\left(s_{i} * x_{j}\right)$ accounts for the experience profiles of earnings across educational groups. The interactions $\left(s_{i} * \pi_{t}\right),\left(x_{j} * \pi_{t}\right)$, and $\left(\gamma_{r} * \pi_{t}\right)$ control for the changing impact 
of education, experience, and micro-region over time. The term $\left(X_{i j r t} * \pi_{t}\right)$ is the interaction between the distribution of the male population and time. The interaction $\left(s_{i} * x_{j} * \pi_{t}\right)$ accounts for variation in the experience profile of earnings by education group and time.

The model above has the implicit assumption that men and women are separated in the labor market. In the broad labor-demand literature, formal tests of separability almost always reject this assumption (Hamermesh 1993). We have the same Census information on the age-education structure for the female and male workforce by micro-region. Thus, the issue of the ability to separate male labor from female labor should be examined. We could include these distributions as additional types of labor in Equation (1), which would allow us to also calculate the coefficients for female workers. However, several difficulties arise regarding this exercise. Most notably, the distributions of female workers by age and education are highly correlated with the distributions of male workers. For example, when the male workforce is older, the female workforce is also older. Likewise, when men are better educated, women are also better educated. Excluding female workers from the equations can bias the estimated impact of own-cohort size on male workers. However, the way this exclusion affects our estimations depends on these positive correlations and the relationships between men and women within and across age-education groups. No prior studies tested how these relationships occur in the labor market. Thus, ultimately, the possible bias of our model is an empirical issue. We examined this question by adding the relative proportions of women to a re-estimation of Equation (1). Not surprisingly, the high positive correlations between the male and female distributions across the age-education categories within micro-regions substantially increased the standard for error. This pattern forced the statistical software to excude several coefficients from the regression model.

We also estimated another set of models by including the female age-education composition for individuals who were employed as a component of the labor market. Thus, we avoided some of the correlation between male and female distributions across age-education groups. This methodology allowed us to evaluate the impact on male earnings that were affected only by women who were actually participating (receiving earnings) in the labor market. This is an important aspect of the difference 
between male and female labor, as female labor force participation has been increasing throughout the decades (Esping-Andersen, 2009; Esping-Andersen et al., 2002).

\section{Results}

Keeping in mind the history of economic development in Brazil, regional disparities, gender inequality, and increasing female participation in the labor market, statistical models were estimated to analyze the impact of changes in the age-education structure on male earnings. These models also included information on the participation of women in the labor market. As noted in Table 1, income increases with age and education for men and women. Furthermore, the earnings of women are lower than those of men in all age-education groups between 1970 and 2000. By taking into account both men and women, it is possible to try to understand the trends of earnings. However, this exercise would require the introduction of control variables that explain the patterns of female earnings. In our analysis, we avoid this problem by estimating how demographic and educational transitions affected male earnings (dependent variable) in each micro-region, by year, and age-education group.

\section{>> Table $1<<<$}

The 1970, 1980, 1991, and 2000 Demographic Censuses have the same type of information per micro-region on the age-education structures for the male and female populations. The distribution of the female population by different age-education groups could be included in the equations for estimates on male income. In practice, we could use the distributions of men and women by age-education groups as independent variables, as a strategy to verify the impact of changes in the age-education structure on male earnings. However, the distribution of the female population by age and education is highly correlated with the distribution of the male population (Table 2). An initial attempt (not shown) was made to examine this issue by adding the regression equation that addressed relative proportions of women in the labor market. As expected, the high positive correlation between the distributions of men and women by their age-education groups in each micro-region caused a considerable increase in the estimated standard 
errors. Although there were not considerable changes in the estimates for the male distributions, this autocorrelation issue led the statistical program to exclude several independent variables.

\section{>> Table $2 \ll<$}

Since female labor force participation has been increasing considerably in recent decades, this information has to be considered in our models. According to IBGE data, the economically active population in Brazil went from 17.1 million people in 1950 to 98.8 million in 2007. During this period, the labor force participation of men rose from 14.6 million to 55.8 million, while female labor force participation varied from 2.5 million to 43.9 million (Alves and Corrêa, 2009). For the participation rate during the period between 1950 and 2007, there was a reduction of these estimates for men and an increase for women. The male labor force participation rate fell from 80.8 percent in 1950 to 72.4 percent in 2007. For women, the participation rate increased from 13.58 percent to 52.35 percent during the same period (Alves and Corrêa, 2009). Taking into account the age range of the population from 15 to 64 years of age, along with information on years of schooling in the 1970, 1980, 1991, and 2000 Demographic Censuses micro-data, the percentage of employed males fell from 80.3 percent in 1970 to 68.5 percent in 2000 (Table 3). On the other hand, the percentage of employed females increased from 21.7 percent in 1970 to 39.6 percent in 2000 .

\section{>> Table $3<<<$}

Table 3 also illustrates that the percentage of employed men and women are not correlated across the different age-education groups in each year. Subsequently, instead of adding the distribution of the female population by age-education groups (Table 2), we only added information on employed women with income (Table 3) to our regression estimates as a set of independent variables. Therefore, a correlation between the distributions of men and women in the age-education groups was avoided. The dependent variable remained the logarithm of the real monthly income of men. The impact on male income was then evaluated, using the distribution of the male population by age-education groups as an independent variable, as well as the distribution of employed women by age-education groups in each 
micro-region and year. This was an important estimation exercise, because female participation in the labor market has grown in recent decades.

Regression results in Table 4 indicate that within each age group, an increase in education has a positive impact on male earnings. Similarly, within each education group, an increase in age also has a positive impact on earnings. These coefficients confirm the income trends exposed in Table 1.

Furthermore, the distribution of males by age-education groups had a negative impact on earnings in 1970, as we expected. However, these impacts are changing over time, as a result of a decrease in the effect of negative cohort-size on earnings. In relation to the groups with the least education, the small proportional sizes of these groups do not have a significant impact on earnings in more recent years. Finally, estimations suggest that there was a significant negative impact on male earnings in 1970 as a result of the distribution of employed females by age-education groups. This impact has been diminishing over the decades, which can be observed by the positive coefficients in the most recent years. The negative impact of female labor on the earnings of males only remain for younger (15-24 years of age) and older (50-64 years of age) groups in 1991 and 2000.

\section{>> Table $4<<<$}

The general results (Table 4) for the coefficients of the male distribution by age-education groups did not differ from Equation (1) in Amaral et al. (2007). Furthermore, these results suggest that the share of female workers had a significant negative impact on male earnings in 1970. This effect has been decreasing over time, as the coefficients in more recent years are positive. Considering changes in age and educational compositions makes a sizeable difference on the estimation of earnings profiles among Brazilian workers. The method developed in this study is not infallible, but it improves previous estimates by including the relationship between male compositional changes, female labor force participation, and male earnings. Therefore, the focus extends beyond the direct impact of age and education. 


\section{Final considerations}

As is suggested by the historical review of economic inequality in Brazil, differences across regions create limitations for the development of the country (Furtado, 1975, 1979, 1984, 2002, 2003, 2009). This regional issue has become a central component during the ongoing Brazilian industrialization process. Furthermore, gender inequality is a barrier to economic development (Esping-Andersen, 2009; EspingAndersen et al., 2002). The increase in female labor force participation diminishes gender and overall inequality. This process is happening in several countries, but all of the issues related to female participation in the labor market have yet to be solved. In Brazil, women continue to receive lower wages than men, even when factoring in age and education (Alves and Corrêa, 2009).

Following this theoretical and historical framework, we analyzed the 1970, 1980, 1991, and 2000 Brazilian Demographic Censuses. Regional disparities, concerning economic outcomes, were taken into account through the use of area and time fixed-effects models. Information on female labor force participation for each age-education group, micro-region and year was also introduced into our models. The main results suggest that the increase in female labor force participation had a negative impact on male earnings in previous decades, for almost all age-education groups. This negative impact has been decreasing between 1970 and 2000. This might be an indication that the labor market has been better assimilating female workers, without compromising male earnings. However, gender inequalities still remain in terms of earnings based on main occupation.

Improvements in educational attainment from 1970 to 2000 were important factors in reducing economic inequality. On one hand, an increase in workers with better education resulted in an overall lowering of income. On the other hand, a reduction of workers with the lowest level of education prevented an even lower income for these groups. At the same time, fertility decline played a central role in the reduction of income inequality in Brazil. A smaller proportion of younger groups in the labor market resulted in an improvement in earnings. Thus, the aging of the population also had a meaningful impact on decreasing inequality. Finally, the increase of female labor force participation had a negative impact in previous decades, which was significant to decreasing the gender gap in relation to earnings. In 
more recent years, the Brazilian economy seems to be more adapted to the inclusion of females in the labor market. However, female labor force participation is still lower than male participation. Important federal, state, and municipal policies to further decrease income and gender inequalities in the country would have to: (1) improve educational attainment in areas that still have a large proportion of people with lower levels of schooling; (2) promote family planning programs in regions that still have higher levels of fertility; and (3) continue to increase female labor force participation, as a strategy to diminish gender inequality, taking into account the different economic structures throughout Brazilian regions.

Our estimation of models utilizing the 24 gender-age-education groups was a significant improvement on previous studies. There are additional variables that can also be included in future analyses, as this exploration of the influence of female workers on the earnings of males in Brazil is constantly changing and progressing due to the newness of available data. We intend to continually update this study as additional information becomes available, for example with the release of the 2010 Brazilian Demographic Census microdata.

\section{References}

Alves, José E. D., and Sônia Corrêa. 2009. "Igualdade e desigualdade de gênero no Brasil: um panorama preliminar, 15 anos depois do Cairo." In Brasil, 15 anos após a Conferência do Cairo. ABEP; UNFPA. Campinas.

Amaral, Ernesto F. L., Daniel S. Hamermesh, Joseph E. Potter, and Eduardo L. G. Rios-Neto. 2007. "Demographic Change and the Structure of Wages: A Demand-Theoretic Analysis for Brazil." NBER Working Paper Series 13533.

Bielschowsky, Ricardo. 2009. Formação Econômica do Brasil: uma obra-prima do estruturalismo cepalino. Brasília: Instituto de Pesquisa Econômica Aplicada (IPEA).

Costa, Letícia. “Aumento da participação feminina: uma tentativa de explicação.” 1990. In Encontro da Associação Brasileira de Estudos Populacionais, 7., Caxambú. Anais... Caxambú: ABEP. v. 2, p.231-243.

Daly, Mary, and Katherine Rake. 2003. Gender and the welfare state: care, work and welfare in Europe and USA. Cambridge: Polity Press.

Esping-Andersen, Gøsta, Duncan Gallie, Anton Hemerijk, and John Myers. 2002. Why We Need a New Welfare State. New York: Oxford University Press.

Esping-Andersen, Gøsta. 2009. The incomplete revolution: adapting to women's new roles. Cambridge: Polity Press. 
Fiori, José Luís. 2000. “A propósito de uma ‘construção interrompida'.” In Celso Furtado e o Brasil, eds. Tavares, M. Conceição. São Paulo: Editora Fundação Perseu Abramo.

Furtado, Celso. 1975. A hegemonia dos Estados Unidos e o subdesenvolvimento da América Latina. Rio de Janeiro: Civilização Brasileira.

Furtado, Celso. 1979. Formação econômica do Brasil. São Paulo: Companhia Editora Nacional.

Furtado, Celso. 1984. Cultura e desenvolvimento em época de crise. Rio de Janeiro: Paz e Terra.

Furtado, Celso. 2002. Em busca de novo modelo. São Paulo: Editora Paz e Terra.

Furtado, Celso. 2003. Entrevista: Lançamento dos Indicadores do Século XX. Rio de Janeiro: Instituto Brasileiro de Geografia e Estatística (IBGE).

Furtado, Celso. 2009. Desenvolvimento e subdesenvolvimento. Rio de Janeiro: Contraponto.

Hamermesh, Daniel S. 1993. Labor Demand. Princeton, NJ: Princeton University Press.

Mendes, Constantino, and Joanílio Teixeira. 2004. "Desenvolvimento Econômico Brasileiro: uma releitura das contribuições de Celso Furtado." Texto para discussão $n^{\circ} 320$. Brasília: Universidade de Brasília.

Nabuco, Maria Regina. 2000. "Estado e projeto nacional nas obras iniciais de Celso Furtado." In Celso Furtado e o Brasil, eds. Tavares, M. Conceição. São Paulo: Editora Fundação Perseu Abramo.

Rios-Neto, Eduardo L. G., and Simone Wajmann. 1994. "Participação feminina na população economicamente ativa no Brasil: alternativas para projeções de níveis e padrões." Pesquisa e Planejamento Econômico, Rio de Janeiro, v. 24, n. 2, p. 203-234, Maio.

Rios-Neto, Eduardo. L. G., and Dulce B. D. A. Batista. 1998. "Segregação ocupacional entre solteiras e casadas: o possível impacto da licença maternidade." In Encontro da Associação Brasileira de Estudos Populacionais, 11. Belo Horizonte. Anais... Belo Horizonte: ABEP. p. 2663-2686.

Soares, Rodrigo, and Bruno Falcão. 2008. "The Demographic Transition and the Sexual Division of Labor." Journal of Political Economy, 116(6).

Souza, Laetícia. 2009. "O efeito dos filhos sobre a participação feminina no mercado de trabalho brasileiro: explorando diversas fontes de variação exógena na fecundidade." PhD Dissertation. Belo Horizonte: Centro de Desenvolvimento e Planejamento Regional (CEDEPLAR), Universidade Federal de Minas Gerais (UFMG).

Wajnman, Simone, Bernardo Queiroz, and Cristina Liberato. 1998. "O crescimento da atividade feminina nos anos noventa no Brasil.” 1998. In Encontro da Associação Brasileira de Estudos Populacionais, 11., Caxambú. Anais... Caxambú: ABEP.

Work Care Synergies. 2011. http://workcaresynergies.eu/ (September 30, 2011). 
Table 1. Male and female mean real monthly earnings from main occupation ${ }^{+}$by age-education group, Brazil, 1970-2000

\begin{tabular}{|c|c|c|c|c|c|c|c|c|}
\hline \multirow{2}{*}{ Age-education group } & \multicolumn{2}{|c|}{1970} & \multicolumn{2}{|c|}{1980} & \multicolumn{2}{|c|}{1991} & \multicolumn{2}{|c|}{2000} \\
\hline & Males & Females & Males & Females & Males & Females & Males & Females \\
\hline $\begin{array}{l}15-24 \text { years; } \\
0-4 \text { years of schooling }\end{array}$ & 158.54 & 100.57 & 276.29 & 146.56 & 196.05 & 123.47 & 213.23 & 146.87 \\
\hline $\begin{array}{l}\text { 15-24 years; } \\
5-8 \text { years of schooling }\end{array}$ & 285.87 & 171.14 & 359.01 & 188.65 & 261.94 & 153.93 & 250.15 & 163.19 \\
\hline $\begin{array}{l}15-24 \text { years; } \\
9+\text { years of schooling }\end{array}$ & 530.31 & 312.25 & 641.81 & 361.47 & 428.00 & 265.46 & 361.56 & 260.98 \\
\hline $\begin{array}{l}25-34 \text { years; } \\
0-4 \text { years of schooling }\end{array}$ & 227.16 & 151.49 & 439.51 & 207.90 & 289.52 & 162.82 & 303.49 & 180.29 \\
\hline $\begin{array}{l}25-34 \text { years; } \\
5-8 \text { years of schooling }\end{array}$ & 585.02 & 268.05 & 818.99 & 316.88 & 472.21 & 227.73 & 459.94 & 256.07 \\
\hline $\begin{array}{l}25-34 \text { years; } \\
9+\text { years of schooling }\end{array}$ & $1,183.87$ & 463.03 & $1,562.22$ & 638.97 & 894.31 & 482.70 & 834.13 & 511.05 \\
\hline $\begin{array}{l}35-49 \text { years; } \\
0-4 \text { years of schooling }\end{array}$ & 273.56 & 172.48 & 551.83 & 242.43 & 381.59 & 188.68 & 394.58 & 208.30 \\
\hline $\begin{array}{l}35-49 \text { years; } \\
5-8 \text { years of schooling }\end{array}$ & 845.03 & 384.19 & $1,316.54$ & 474.19 & 755.74 & 335.18 & 668.49 & 317.34 \\
\hline $\begin{array}{l}35-49 \text { years; } \\
9+\text { years of schooling }\end{array}$ & $1,661.43$ & 574.40 & $2,348.69$ & 792.60 & $1,557.74$ & 684.45 & $1,482.51$ & 761.92 \\
\hline $\begin{array}{l}50-64 \text { years; } \\
0-4 \text { years of schooling }\end{array}$ & 275.46 & 179.59 & 553.77 & 270.25 & 380.52 & 202.94 & 436.81 & 234.93 \\
\hline $\begin{array}{l}50-64 \text { years; } \\
5-8 \text { years of schooling }\end{array}$ & 978.13 & 505.29 & $1,587.19$ & 675.32 & 918.25 & 413.44 & 913.82 & 409.95 \\
\hline $\begin{array}{l}50-64 \text { years; } \\
9+\text { years of schooling }\end{array}$ & $1,724.94$ & 664.49 & $2,823.26$ & 940.49 & $1,826.73$ & 751.04 & $2,080.80$ & 912.38 \\
\hline Grand mean & 711.47 & 314.40 & $1,093.98$ & 430.86 & 694.56 & 331.22 & 699.24 & 363.49 \\
\hline
\end{tabular}

${ }^{+}$Nominal income was converted to base 1 in January 2002, taking into account changes in currency and inflation.

Source: 1970, 1980, 1991 and 2000 Brazilian Demographic Censuses. 
Table 2. Percentage distribution of the male and female working-age population by age-education group, Brazil, 1970-2000

\begin{tabular}{|c|c|c|c|c|c|c|c|c|}
\hline \multirow{2}{*}{ Age-education group } & \multicolumn{2}{|c|}{1970} & \multicolumn{2}{|c|}{1980} & \multicolumn{2}{|c|}{1991} & \multicolumn{2}{|c|}{2000} \\
\hline & Males & Females & Males & Females & Males & Females & Males & Females \\
\hline $\begin{array}{l}15-24 \text { years; } \\
0-4 \text { years of schooling }\end{array}$ & 28.19 & 29.14 & 20.59 & 19.51 & 14.61 & 11.98 & 9.04 & 6.51 \\
\hline $\begin{array}{l}\text { 15-24 years; } \\
5-8 \text { years of schooling }\end{array}$ & 5.38 & 5.19 & 10.53 & 10.49 & 12.09 & 12.13 & 12.46 & 11.44 \\
\hline $\begin{array}{l}\text { 15-24 years; } \\
9+\text { years of schooling }\end{array}$ & 2.74 & 3.07 & 5.87 & 6.79 & 5.97 & 7.55 & 10.24 & 12.47 \\
\hline $\begin{array}{l}25-34 \text { years; } \\
0-4 \text { years of schooling }\end{array}$ & 19.71 & 20.29 & 16.39 & 16.60 & 12.41 & 11.95 & 8.82 & 7.56 \\
\hline $\begin{array}{l}25-34 \text { years; } \\
5-8 \text { years of schooling }\end{array}$ & 1.98 & 1.67 & 3.90 & 3.57 & 6.82 & 6.45 & 7.63 & 7.21 \\
\hline $\begin{array}{l}25-34 \text { years; } \\
9+\text { years of schooling }\end{array}$ & 2.00 & 1.79 & 4.77 & 4.89 & 7.40 & 8.35 & 8.12 & 9.72 \\
\hline $\begin{array}{l}35-49 \text { years; } \\
0-4 \text { years of schooling }\end{array}$ & 22.66 & 22.81 & 19.02 & 19.82 & 17.11 & 17.57 & 13.32 & 13.17 \\
\hline $\begin{array}{l}35-49 \text { years; } \\
5-8 \text { years of schooling }\end{array}$ & 1.62 & 1.29 & 2.39 & 2.04 & 3.67 & 3.47 & 6.73 & 6.58 \\
\hline $\begin{array}{l}35-49 \text { years; } \\
9+\text { years of schooling }\end{array}$ & 1.59 & 1.13 & 2.84 & 2.33 & 5.54 & 5.52 & 8.46 & 9.33 \\
\hline $\begin{array}{l}50-64 \text { years; } \\
0-4 \text { years of schooling }\end{array}$ & 12.84 & 12.70 & 11.72 & 12.40 & 11.49 & 12.52 & 10.36 & 11.31 \\
\hline $\begin{array}{l}50-64 \text { years; } \\
5-8 \text { years of schooling }\end{array}$ & 0.65 & 0.48 & 0.94 & 0.80 & 1.16 & 1.11 & 1.99 & 2.00 \\
\hline $\begin{array}{l}50-64 \text { years; } \\
9+\text { years of schooling }\end{array}$ & 0.62 & 0.43 & 1.05 & 0.76 & 1.72 & 1.41 & 2.84 & 2.72 \\
\hline Grand total & $25,760,600$ & $\mathbf{2 6 , 0 3 7 , 5 3 7}$ & $32,613,947$ & $33,695,904$ & $43,434,546$ & $45,265,548$ & $53,177,953$ & $55,440,183$ \\
\hline
\end{tabular}


Table 3. Percentage of employed males and females by age-education group, Brazil, 1970-2000

\begin{tabular}{|c|c|c|c|c|c|c|c|c|}
\hline \multirow{2}{*}{ Age-education group } & \multicolumn{2}{|c|}{1970} & \multicolumn{2}{|c|}{1980} & \multicolumn{2}{|c|}{1991} & \multicolumn{2}{|c|}{2000} \\
\hline & Males & Females & Males & Females & Males & Females & Males & Females \\
\hline $\begin{array}{l}15-24 \text { years; } \\
0-4 \text { years of schooling }\end{array}$ & 61.10 & 21.01 & 67.43 & 25.72 & 61.07 & 24.33 & 47.52 & 20.81 \\
\hline $\begin{array}{l}\text { 15-24 years; } \\
5-8 \text { years of schooling }\end{array}$ & 44.32 & 21.25 & 61.50 & 31.80 & 62.26 & 31.59 & 46.77 & 24.39 \\
\hline $\begin{array}{l}15-24 \text { years; } \\
9+\text { years of schooling }\end{array}$ & 45.59 & 38.00 & 61.51 & 46.14 & 64.05 & 48.19 & 56.24 & 42.96 \\
\hline $\begin{array}{l}25-34 \text { years; } \\
0-4 \text { years of schooling }\end{array}$ & 92.06 & 16.31 & 91.17 & 23.29 & 88.85 & 28.07 & 74.23 & 31.45 \\
\hline $\begin{array}{l}25-34 \text { years; } \\
5-8 \text { years of schooling }\end{array}$ & 93.57 & 33.61 & 94.73 & 36.38 & 91.14 & 38.28 & 82.68 & 42.76 \\
\hline $\begin{array}{l}25-34 \text { years; } \\
9+\text { years of schooling }\end{array}$ & 91.00 & 65.04 & 93.69 & 64.76 & 92.35 & 63.63 & 87.74 & 65.18 \\
\hline $\begin{array}{l}35-49 \text { years; } \\
0-4 \text { years of schooling }\end{array}$ & 95.12 & 18.22 & 89.93 & 24.05 & 90.44 & 31.06 & 75.80 & 36.16 \\
\hline $\begin{array}{l}35-49 \text { years; } \\
5-8 \text { years of schooling }\end{array}$ & 97.00 & 35.99 & 93.39 & 36.90 & 91.84 & 42.76 & 82.65 & 47.59 \\
\hline $\begin{array}{l}35-49 \text { years; } \\
9+\text { years of schooling }\end{array}$ & 96.45 & 63.43 & 96.13 & 66.76 & 94.42 & 67.29 & 89.72 & 66.85 \\
\hline $\begin{array}{l}50-64 \text { years; } \\
0-4 \text { years of schooling }\end{array}$ & 91.74 & 19.63 & 74.91 & 15.60 & 73.95 & 18.18 & 59.87 & 21.07 \\
\hline $\begin{array}{l}50-64 \text { years; } \\
5-8 \text { years of schooling }\end{array}$ & 95.76 & 38.59 & 70.79 & 24.16 & 65.57 & 26.37 & 62.11 & 31.92 \\
\hline $\begin{array}{l}50-64 \text { years; } \\
9+\text { years of schooling }\end{array}$ & 94.74 & 60.74 & 79.81 & 39.89 & 68.94 & 38.68 & 67.74 & 43.08 \\
\hline Total employed & 80.34 & 21.71 & 79.42 & 29.33 & 78.88 & 35.29 & 68.46 & 39.61 \\
\hline
\end{tabular}


Table 4. Fixed-effects estimates on the logarithm of male mean real monthly earnings from main occupation $^{+}$(dependent variable), based on Equation (1) and including distribution of employed females, Brazil, 1970-2000

\begin{tabular}{|c|c|c|c|c|}
\hline \multirow{3}{*}{$\begin{array}{l}\text { Variables } \\
\text { Constant }\end{array}$} & \multicolumn{4}{|c|}{ Coefficients } \\
\hline & $5.28 * * *$ & \multirow{2}{*}{\multicolumn{3}{|c|}{ Interactions with year }} \\
\hline & & & & \\
\hline Age-education indicators & & 1980 & 1991 & 2000 \\
\hline 15-24 years; 0-4 years of schooling (reference group) & - & - & - & - \\
\hline $15-24$ years; $5-8$ years of schooling & $1.09 * * *$ & $-0.59 * * *$ & $-0.48 * * *$ & $-0.69 * * *$ \\
\hline $15-24$ years; $9+$ years of schooling & $1.47 * * *$ & $-0.36 * * *$ & $-0.42 * * *$ & $-0.59 * * *$ \\
\hline $25-34$ years; $0-4$ years of schooling & $0.51 * * *$ & 0.06 & -0.02 & -0.13 \\
\hline $25-34$ years; $5-8$ years of schooling & $1.70 * * *$ & $-0.49 * * *$ & $-0.65 * * *$ & $-0.72 * * *$ \\
\hline $25-34$ years; $9+$ years of schooling & $2.36 * * *$ & $-0.54 * * *$ & $-0.75 * * *$ & $-0.97 * * *$ \\
\hline $35-49$ years; $0-4$ years of schooling & $0.78 * * *$ & 0.13 & 0.14 & 0.03 \\
\hline $35-49$ years; $5-8$ years of schooling & $2.00 * * *$ & $-0.30 * *$ & $-0.46^{* * *}$ & $-0.70 * * *$ \\
\hline $35-49$ years; $9+$ years of schooling & $2.63 * * *$ & $-0.46 * * *$ & $-0.59 * * *$ & $-0.75 * * *$ \\
\hline 50-64 years; $0-4$ years of schooling & $0.92 * * *$ & -0.07 & -0.19 & -0.11 \\
\hline $50-64$ years; $5-8$ years of schooling & $2.08 * * *$ & $-0.31 * *$ & $-0.43 * * *$ & $-0.55 * * *$ \\
\hline \multirow[t]{2}{*}{ 50-64 years; $9+$ years of schooling } & $2.54 * * *$ & $-0.35 * * *$ & $-0.33 * * *$ & $-0.39 * * *$ \\
\hline & & \multicolumn{3}{|c|}{ Interactions with year } \\
\hline Distribution of males by age-education groups & & 1980 & 1991 & 2000 \\
\hline 15-24 years; 0-4 years of schooling & 0.35 & -0.26 & 0.23 & -0.42 \\
\hline $15-24$ years; $5-8$ years of schooling & $-5.56 * * *$ & $2.82 * * *$ & $3.89 * * *$ & $3.41 * * *$ \\
\hline $15-24$ years; $9+$ years of schooling & $-7.36 * * *$ & $4.97 * * *$ & $4.38 * * *$ & $7.86 * * *$ \\
\hline 25-34 years; 0-4 years of schooling & $0.93 *$ & $-1.18^{*}$ & $-1.78 * *$ & $-2.03 * * *$ \\
\hline $25-34$ years; $5-8$ years of schooling & $-10.66 * * *$ & $6.05 * * *$ & $6.94 * * *$ & $7.16 * * *$ \\
\hline $25-34$ years; $9+$ years of schooling & $-9.44 * * *$ & $6.44 * * *$ & $8.09 * * *$ & $9.02 * * *$ \\
\hline $35-49$ years; $0-4$ years of schooling & 0.86 & -0.16 & -1.21 & $-1.96 * *$ \\
\hline $35-49$ years; $5-8$ years of schooling & $-6.81 * *$ & 1.32 & 0.26 & 2.60 \\
\hline $35-49$ years; $9+$ years of schooling & $-7.35 * * *$ & $5.42 *$ & 3.28 & $5.92 * *$ \\
\hline 50-64 years; $0-4$ years of schooling & -0.51 & 1.13 & 1.17 & -0.42 \\
\hline $50-64$ years; $5-8$ years of schooling & $-20.76 * *$ & $19.71 *$ & 8.50 & $24.86 * *$ \\
\hline \multirow[t]{2}{*}{ 50-64 years; $9+$ years of schooling } & $-18.30 * *$ & 10.92 & 8.62 & $17.33 * *$ \\
\hline & & \multicolumn{3}{|c|}{ Interactions with year } \\
\hline Distribution of employed females by age-education groups & & 1980 & 1991 & 2000 \\
\hline $15-24$ years; $0-4$ years of schooling & 0.27 & -0.44 & $-0.98 * *$ & -0.33 \\
\hline $15-24$ years; $5-8$ years of schooling & $-2.39 * * *$ & $2.24 * * *$ & $1.46^{* *}$ & $2.63 * * *$ \\
\hline $15-24$ years; $9+$ years of schooling & $-1.16^{*}$ & $-1.42 *$ & -0.05 & $-2.15 * *$ \\
\hline 25-34 years; 0-4 years of schooling & $-0.99 * * *$ & 0.36 & $1.41 * *$ & $1.90 * *$ \\
\hline $25-34$ years; $5-8$ years of schooling & $-3.98 * * *$ & $3.53 * *$ & $5.10 * * *$ & $4.26 * * *$ \\
\hline $25-34$ years; $9+$ years of schooling & $-1.78 * *$ & $1.38 *$ & $1.95 * *$ & $1.62 *$ \\
\hline $35-49$ years; $0-4$ years of schooling & $-1.19 * * *$ & $-1.00 * *$ & 0.32 & $0.93 *$ \\
\hline $35-49$ years; $5-8$ years of schooling & $-6.54 * * *$ & 1.56 & $6.97 * * *$ & $7.50 * * *$ \\
\hline $35-49$ years; $9+$ years of schooling & -2.04 & 1.94 & $4.67 * * *$ & $3.03 * *$ \\
\hline 50-64 years; $0-4$ years of schooling & $-0.83 * * *$ & $-2.53 * * *$ & -0.81 & 0.50 \\
\hline 50-64 years; $5-8$ years of schooling & -0.45 & $-19.62 *$ & 1.81 & $-16.92 *$ \\
\hline $50-64$ years; $9+$ years of schooling & $6.45^{*}$ & 6.92 & $11.60 * *$ & -2.43 \\
\hline Number of observations & 19,727 & & & \\
\hline Number of groups & 2,008 & & & \\
\hline Fraction of variance due to area-time fixed effects & 0.87 & & & \\
\hline $\mathrm{F}(140 ; 17,579):$ all coefficients $=0$ & $1,975 * * *$ & & & \\
\hline $\mathrm{F}(2,007 ; 17,579):$ area-time fixed effects $=0$ & $16.00 * * *$ & & & \\
\hline
\end{tabular}

